\title{
Pro-health behavior of Łęczna town residents concerning protection against UV radiation
}

\begin{abstract}
Introduction. The fashion for a tan appeared at the beginning of the twentieth century, in the era of technological progress and urbanization with medical knowledge about heliotherapy and the promotion of the tan by fashion designer Coco Chanel being a contributing factor in it. The International Agency for Research on Cancer classified the UV to the first group of carcinogens but despite these warnings the increase in exposure to UV radiation has been seen in recent years. New solariums have been created around the world so that people can enjoy a tan all year round, no matter what the weather conditions are.

Aim. The aim of the study was to assess the attitudes and behaviors related to UV radiation exposure among residents of Łęczna.

Material and methods. A survey conducted among 180 people inquiring about sociodemographic characteristics and attitudes and behaviours associated with exposure to UV radiation while tanning.

Results. Statistical analysis of the data obtained in the study showed that the socio- demographic characteristics affect the attitudes and behaviour associated with exposure to UV radiation. Suntan is believed to be significantly more fashionable among women, people with secondary education who have no permanent relationships.

Conclusion. There is a need for preventive actions and educational programs concerning the dangers of UV radiation in order to develop not only knowledge but also the correct behaviour in society.
\end{abstract}

Keywords: pro-health education, health behavior, tan.

DOI: $10.1515 /$ pjph-2016-0015

\section{INTRODUCTION}

There were various times in human history when light skin was considered a sign of both affluence and health. In the $18^{\text {th }}$ century a pale and alabaster complexion was popular in South America and Europe but tanned skin was considered an indication of one's being a part of a lower social class [1]. The tan, considered as a sign of good health, became popular at the beginning of the $20^{\text {th }}$ century, the era when both technological progress happened and medical knowledge about heliotherapy was spread. In addition, the famous fashion designer Coco Chanel also popularized the tan. It needs emphasizing that an alabaster skin has been appreciated throughout many centuries and as such entered the history books [2,3]. In the 1980s, some self-tan products appeared on the market. As a result, the tanning industry has grown significantly. Limited knowledge about the harmful effects of UV radiation and a false belief about lack of any tanning-related side effects also contributed to it [4]. International Agency for Research on Cancer and World Health Organization classified UV radiation to group I of carcinogens [3] but despite the warnings one might observe the increase in the exposure to UV radiation in recent years.
This was a consequence of the hype about tan created in the media, as well as the human migration to low latitude countries [5]. Also, the increase in the number of solariums offering their services all year round contributed to it. People of different socio-economic status tend to use self-tan mainly to have a fast and beautiful tan. The number of people going to tanning salons in Poland is constantly on the increase [6]. Between 2004 and 2007, at least one salon offering tanning services was being open every day [7]. Using a solariums makes it possible to become independent of a natural, golden tan. Lamps used in solariums emit UVA radiation at the greatest amount, whereas UVB radiation constitutes only $0.7-3.0 \%$ of the whole radiation reaching the surface of the skin.

Tan is a process during which UVA radiation penetrates the skin on its full surface. It leads to producing of the so-called instant tan, during which melanin precursors stored in the skin become oxygenated to bronze melanin.

To a large extent biological cutaneous reactions are dependent on a cumulative, aggregated dose of radiation as well as a range of the spectrum [2]. UVA radiation exerts an effect on the skin by creating free radicals. An early photochemical effect of UV radiation is the ability to modulate the body's

${ }^{1}$ Faculty of Law and Administration, Maria Curie-Skłodowska University, Poland

2 Department of Prosthodontics, Mediacal University of Lublin, Poland

${ }^{3}$ Chair and Department of Paedodontics, Mediacal University of Lublin, Poland

${ }^{4}$ Department of Biological Basis of Animal Production, University of Life Science in Lublin, Poland 
immune system. Thus, it leads to the suppression of the immune response in the contact allergy reaction [8-10]. The intensity of erythema depends on a number of factors, like the wavelength of UV radiation and its energy levels, the length of exposure to radiation, the distance between the radiation source and the skin, skin phototype, its sensitivity and part of the body. The risk of malignant transformations and converting erythema into melanoma is considerably high $[11,12]$.

Currently, there are requirements limiting the emission of $\mathrm{UV}$ radiation to $0.3 \mathrm{~V} / \mathrm{m}^{2}$ in solariums. Only new appliances are subject to this regulation whereas old ones, which constitute approximately $70 \%$ in Poland $[3,13]$, still emit radiation power twice as much.

UVB and UVA radiation is responsible for the process of cancerogenesis, i.e. the development of epidermal and melanotic tumours. The most frequent melanotic skin lesions are lentigo solaris, so called lentigo senilis appearing in people at the age 30 to 50 , on the skin area affected by solar and solarium radiation. Precancerous conditions connected with UV radiation include: solar keratosis, cutaneous horns, xeroderma pigmentosum, lentigo maligna. These skin lesions, after specified time, can transform into malignant neoplasm.

During recent years one can observe an interest in the harmful impact of UV radiation on the skin. One can also observe the development of medicine in the field of early detection as well as treatment and preventive measures taken for the development of skin diseases. Everyday behaviour can affect the length of human life [14].

\section{AIM}

The aim of the study was to assess the attitudes and behaviors related to exposure to UV radiation among residents of a small town, looking at residents of of Łęczna.

\section{MATERIALS AND METHODS}

A survey based on a questionnaire was conducted among the residents of Łęczna. The survey was anonymous and respondents were informed about the purpose of the survey. The survey was conducted among 180 people, $60.56 \%(\mathrm{n}=109)$ of which were women while $39.44 \%(n=71)$ were men. The survey was conducted from March to May 2014 and the questions on age, sex, marital status and educational background were asked. In the questionnaire there were questions concerning behaviour connected with exposure to UV radiation.

The results of the survey were submitted for a statistical analysis. Statistical significance of tested dependants was assessed by using a nonparametric test $\chi^{2} .5 \%$ non sequitur was taken indicating the occurrence of statistically significant differences and dependants. Statistical surveys were conducted using a computer software STATISTICA v.10.0 (StatSoft, Polska).

\section{RESULTS}

A statistical analysis of the data obtained in the study revealed that the socio-demographic characteristics affect the attitudes and behaviors associated with exposure to UV radiation.

The fashion for a tan was highly dependent on educational background and marital status of respondents. A tan is

TABLE 1. The opinion of the respondents concerning the fashion of sunbathing.

\begin{tabular}{|c|c|c|c|c|c|c|c|c|c|c|}
\hline \multirow[b]{2}{*}{$\begin{array}{l}\text { Do you think } \\
\text { that the tan } \\
\text { is fashionable? }\end{array}$} & \multicolumn{3}{|c|}{ Sex } & \multicolumn{4}{|c|}{ Education } & \multicolumn{3}{|c|}{ Martial status } \\
\hline & $\begin{array}{c}\text { Female } \\
\mathrm{n} \\
\%\end{array}$ & $\begin{array}{c}\text { Male } \\
\mathrm{n} \\
\%\end{array}$ & $\begin{array}{l}\text { All } \\
\mathrm{n} \\
\%\end{array}$ & $\begin{array}{c}\text { Primary } \\
\mathrm{n} \\
\%\end{array}$ & $\begin{array}{c}\text { Secondary } \\
\mathrm{n} \\
\%\end{array}$ & $\begin{array}{l}\text { High } \\
\mathrm{n} \\
\%\end{array}$ & $\begin{array}{c}\text { All } \\
\mathrm{n} \\
\%\end{array}$ & $\begin{array}{l}\text { Single } \\
\text { n } \\
\%\end{array}$ & $\begin{array}{c}\text { Permanent } \\
\text { relationship } \\
\mathrm{n} \\
\% \\
\end{array}$ & $\begin{array}{l}\text { All } \\
\mathrm{n} \\
\%\end{array}$ \\
\hline yes & $\begin{array}{c}58 \\
53.21\end{array}$ & $\begin{array}{c}29 \\
40.85\end{array}$ & $\begin{array}{c}87 \\
100\end{array}$ & $\begin{array}{c}9 \\
36.00\end{array}$ & $\begin{array}{c}54 \\
59.34\end{array}$ & $\begin{array}{c}24 \\
37.50\end{array}$ & $\begin{array}{c}87 \\
48.33\end{array}$ & $\begin{array}{c}56 \\
57.14\end{array}$ & $\begin{array}{c}31 \\
37.80\end{array}$ & $\begin{array}{c}87 \\
48.33\end{array}$ \\
\hline no & $\begin{array}{c}35 \\
32.11\end{array}$ & $\begin{array}{c}8 \\
11.27\end{array}$ & $\begin{array}{c}43 \\
100\end{array}$ & $\begin{array}{c}5 \\
20.00\end{array}$ & $\begin{array}{c}15 \\
16.48\end{array}$ & $\begin{array}{c}23 \\
35.94\end{array}$ & $\begin{array}{c}43 \\
23.89\end{array}$ & $\begin{array}{c}19 \\
19.39\end{array}$ & $\begin{array}{c}24 \\
29.27\end{array}$ & $\begin{array}{c}43 \\
23.89\end{array}$ \\
\hline I do not know & $\begin{array}{c}16 \\
14.68\end{array}$ & $\begin{array}{c}34 \\
47.88\end{array}$ & $\begin{array}{c}50 \\
100\end{array}$ & $\begin{array}{c}11 \\
44.00\end{array}$ & $\begin{array}{c}22 \\
24.18\end{array}$ & $\begin{array}{c}17 \\
26.56\end{array}$ & $\begin{array}{c}50 \\
27.78\end{array}$ & $\begin{array}{c}23 \\
23.47\end{array}$ & $\begin{array}{c}27 \\
32.93\end{array}$ & $\begin{array}{c}50 \\
27.78\end{array}$ \\
\hline All & $\begin{array}{l}109 \\
100\end{array}$ & $\begin{array}{c}71 \\
100\end{array}$ & $\begin{array}{l}180 \\
100\end{array}$ & $\begin{array}{c}25 \\
100\end{array}$ & $\begin{array}{c}91 \\
100\end{array}$ & $\begin{array}{c}64 \\
100\end{array}$ & $\begin{array}{l}180 \\
100\end{array}$ & $\begin{array}{c}98 \\
100\end{array}$ & $\begin{array}{c}82 \\
100\end{array}$ & $\begin{array}{l}180 \\
100\end{array}$ \\
\hline Statistical analysis & \multicolumn{3}{|c|}{$\mathrm{Chi}^{2}=26.25 ; \mathrm{p}<0.00001$} & \multicolumn{4}{|c|}{$\mathrm{Chi}^{2}=13.59 ; \mathrm{p}=0.009$} & \multicolumn{3}{|c|}{$\mathrm{Chi}^{2}=6.72 ; \mathrm{p}=0.03$} \\
\hline
\end{tabular}

TABLE 2. The regularity of the sunbathing among the respondents.

\begin{tabular}{|c|c|c|c|c|c|c|c|c|c|c|c|c|}
\hline \multirow[b]{2}{*}{$\begin{array}{c}\text { Regularity } \\
\text { of the sunbathing }\end{array}$} & \multicolumn{5}{|c|}{ Age } & \multicolumn{3}{|c|}{ Martial status } & \multicolumn{4}{|c|}{ Activity on the labour market } \\
\hline & $\begin{array}{c}<20 \\
\mathrm{n} \\
\%\end{array}$ & $\begin{array}{c}21-35 \\
\mathrm{n} \\
\%\end{array}$ & $\begin{array}{c}36-50 \\
\mathrm{n} \\
\%\end{array}$ & $\begin{array}{c}>50 \\
\mathrm{n} \\
\%\end{array}$ & $\begin{array}{c}\text { All } \\
\mathrm{n} \\
\%\end{array}$ & $\begin{array}{c}\text { Single } \\
\mathrm{n} \\
\%\end{array}$ & $\begin{array}{c}\text { Permanent } \\
\text { relationship } \\
\mathrm{n} \\
\%\end{array}$ & $\begin{array}{c}\text { All } \\
\mathrm{n} \\
\%\end{array}$ & $\begin{array}{c}\text { Working } \\
\mathrm{n} \\
\%\end{array}$ & $\begin{array}{c}\text { Student/ } \\
\text { Unemployed } \\
\mathrm{n} \\
\%\end{array}$ & $\begin{array}{c}\text { Retired/ } \\
\text { Pensioner } \\
\mathrm{n} \\
\%\end{array}$ & $\begin{array}{l}\text { All } \\
\mathrm{n} \\
\%\end{array}$ \\
\hline Regular & $\begin{array}{c}2 \\
10.53\end{array}$ & $\begin{array}{c}5 \\
5.95\end{array}$ & $\begin{array}{c}1 \\
2.63\end{array}$ & $\begin{array}{c}2 \\
5.13\end{array}$ & $\begin{array}{c}10 \\
5.56\end{array}$ & $\begin{array}{c}7 \\
7.14\end{array}$ & $\begin{array}{c}3 \\
3.66\end{array}$ & $\begin{array}{c}10 \\
5.56\end{array}$ & $\begin{array}{c}7 \\
6.67\end{array}$ & $\begin{array}{c}3 \\
5.26\end{array}$ & $\begin{array}{c}0 \\
0.00\end{array}$ & $\begin{array}{c}10 \\
5.56\end{array}$ \\
\hline During holiday & $\begin{array}{c}14 \\
76.68\end{array}$ & $\begin{array}{c}56 \\
66.67\end{array}$ & $\begin{array}{c}20 \\
52.63\end{array}$ & $\begin{array}{c}15 \\
38.41\end{array}$ & $\begin{array}{c}105 \\
58.33\end{array}$ & $\begin{array}{c}66 \\
67.35\end{array}$ & $\begin{array}{c}39 \\
47.56\end{array}$ & $\begin{array}{c}105 \\
58.33\end{array}$ & $\begin{array}{c}57 \\
54.29\end{array}$ & $\begin{array}{c}42 \\
73.68\end{array}$ & $\begin{array}{c}6 \\
33.33\end{array}$ & $\begin{array}{c}105 \\
58.33\end{array}$ \\
\hline Occasionally/Never & $\begin{array}{c}3 \\
15.79\end{array}$ & $\begin{array}{c}23 \\
27.38\end{array}$ & $\begin{array}{c}17 \\
44.74\end{array}$ & $\begin{array}{c}22 \\
56.41\end{array}$ & $\begin{array}{c}65 \\
36.11\end{array}$ & $\begin{array}{c}25 \\
25.51\end{array}$ & $\begin{array}{c}40 \\
48.78\end{array}$ & $\begin{array}{c}65 \\
36.11\end{array}$ & $\begin{array}{c}41 \\
39.04\end{array}$ & $\begin{array}{c}12 \\
21.06\end{array}$ & $\begin{array}{c}12 \\
66.66\end{array}$ & $\begin{array}{c}65 \\
36.11\end{array}$ \\
\hline All & $\begin{array}{c}19 \\
100\end{array}$ & $\begin{array}{c}84 \\
100\end{array}$ & $\begin{array}{c}38 \\
100\end{array}$ & $\begin{array}{c}39 \\
100\end{array}$ & $\begin{array}{l}180 \\
100\end{array}$ & $\begin{array}{c}98 \\
100\end{array}$ & $\begin{array}{c}82 \\
100\end{array}$ & $\begin{array}{l}180 \\
100\end{array}$ & $\begin{array}{l}105 \\
100\end{array}$ & $\begin{array}{c}57 \\
100\end{array}$ & $\begin{array}{c}18 \\
100\end{array}$ & $\begin{array}{l}180 \\
100\end{array}$ \\
\hline Statistical analysis & \multicolumn{5}{|c|}{$\mathrm{Chi}^{2}=15.26 ; \mathrm{p}=0.02 *$} & \multicolumn{3}{|c|}{$\mathrm{Chi}^{2}=10.67 ; \mathrm{p}=0.005^{*}$} & \multicolumn{4}{|c|}{$\mathrm{Chi}^{2}=14.25 ; \mathrm{p}=0.007^{*}$} \\
\hline
\end{tabular}


more often considered fashionable by people who have completed secondary education, as well as those who stay single. It might be an indicator of the prevailing cult of beauty related to tanned skin, which is generally associated with good health. Detailed data is presented in Table 1.

The most frequently surveyed respondents tan only on holiday or during their leave $58.33 \%(n=105), 27.78 \%(n=50)$ respondents tan rarely whereas $5.56 \%(\mathrm{n}=10)$ respondents tan on a regular basis and $8.33 \%(n=15)$ respondents never tan. Statistical analysis revealed a relationship between the regularity of tanning and age, marital status and professional activity of the respondents. More information on that is presented in Table 2. Such data dependency was not shown in reference to gender $(p=0.38)$ and educational background $(p=0.10)$. Analysing this aspect of tanning one can suppose that people under the age of 20, being single and in work more frequently get tan in comparison to the other groups, which might result from a desire to be attractive to others. Regrettably, the trend towards dark complexion is still prevailing mainly among young people and it is not always the consequence of regular tanning or using self- tanners. Most pensioners and annuitants get tan intermittently or never, which can be connected with the fear of appearing frequently at that age melanoderma and dermal papillae that might turn into neoplasm or with the fear of showing one's imperfect body in public places such as a beach or swimming pool.

As a result of the analysis, some statistically significant relations between sex, age, marital status and a preferred way of tanning chosen by the respondents (Table 3). 75.56\% $(n=136)$ of people, mainly at the age of $21-35$, men and people in permanent relationships prefer sun tanning. $13.88 \%(n=25)$ of respondents tan both in the sun and in the sunbeds. $10.56 \%$ $(n=19)$ of respondents admitted that they never tan. The fact that some $80 \%$ of respondents do not tan in the tanning bed and their skin is not exposed to higher levels of UVA radiation in a short time is particularly gratifying. The decision to resign from the artificial sources of tanning may result from prophylactic information from the media on the insalubrity of this way of tanning. One can observe that the most frequent way of tanning is in the sun, however, the use the solariums is more prevalent among women who can have the tan regardless of the weather conditions. Concerning the length of exposure to the sun during holiday, most respondents spend 1 to 3 hours $(43.33 \%), 28.89 \%$ of the respondents spend no more than 1 hour sunbathing, and $8.33 \%$ of respondents were exposed to the sun for less than 15 minutes. Almost $20 \%$ of respondents stay out in the sun for more than 3 hours a day.

Research has shown that $43.89 \%$ of respondents can correctly match sunscreen products containing an SPF filter to their phototype, which contributes to minimising the risk of possible sunburn. The analysis showed that people with higher education, in relationships and in active employment could properly select an effective sunscreen matching their skin phototype, this data dependency turned out to be highly statistically significant also taking gender of respondents into consideration. Detailed data referring to dependence of this variable on analysed variables was presented in Table 4. Data analysis did not show the connection between the age of respondents and the choice of a filter.

TABLE 3. Preferred method of tanning.

\begin{tabular}{|c|c|c|c|c|c|c|c|c|c|c|c|}
\hline \multirow[b]{2}{*}{$\begin{array}{l}\text { Preferred method } \\
\text { of tanning }\end{array}$} & \multicolumn{3}{|c|}{ Sex } & \multicolumn{5}{|c|}{ Age } & \multicolumn{3}{|c|}{ Martial status } \\
\hline & $\begin{array}{c}\text { Female } \\
\mathrm{n} \\
\%\end{array}$ & $\begin{array}{c}\text { Male } \\
\mathrm{n} \\
\%\end{array}$ & $\begin{array}{c}\text { All } \\
\mathrm{n} \\
\%\end{array}$ & $\begin{array}{c}<20 \\
\mathrm{n} \\
\%\end{array}$ & $\begin{array}{c}21-35 \\
\mathrm{n} \\
\%\end{array}$ & $\begin{array}{c}36-50 \\
\mathrm{n} \\
\%\end{array}$ & $\begin{array}{c}>50 \\
\mathrm{n} \\
\%\end{array}$ & $\begin{array}{c}\text { All } \\
\mathrm{n} \\
\%\end{array}$ & $\begin{array}{c}\text { Single } \\
\mathrm{n} \\
\%\end{array}$ & $\begin{array}{c}\text { Permanent } \\
\text { relationship } \\
\mathrm{n} \\
\%\end{array}$ & $\begin{array}{c}\text { All } \\
\mathrm{n} \\
\%\end{array}$ \\
\hline Sun tanning & $\begin{array}{c}76 \\
69.72\end{array}$ & $\begin{array}{c}60 \\
84.51\end{array}$ & $\begin{array}{c}136 \\
75.56\end{array}$ & $\begin{array}{c}14 \\
73.68\end{array}$ & $\begin{array}{c}65 \\
77.38\end{array}$ & $\begin{array}{c}29 \\
76.32\end{array}$ & $\begin{array}{c}28 \\
71.79\end{array}$ & $\begin{array}{c}136 \\
75.56\end{array}$ & $\begin{array}{c}72 \\
73.47\end{array}$ & $\begin{array}{c}64 \\
78.05\end{array}$ & $\begin{array}{c}136 \\
75.56\end{array}$ \\
\hline Sunbeds & $\begin{array}{c}24 \\
22.02\end{array}$ & $\begin{array}{c}1 \\
1.41 \\
\end{array}$ & $\begin{array}{c}25 \\
13.88 \\
\end{array}$ & $\begin{array}{c}5 \\
26.32 \\
\end{array}$ & $\begin{array}{c}13 \\
15.48 \\
\end{array}$ & $\begin{array}{c}5 \\
13.15 \\
\end{array}$ & $\begin{array}{c}2 \\
5.13 \\
\end{array}$ & $\begin{array}{c}25 \\
13.88 \\
\end{array}$ & $\begin{array}{c}20 \\
20.41 \\
\end{array}$ & $\begin{array}{c}5 \\
6.10 \\
\end{array}$ & $\begin{array}{c}25 \\
13.88 \\
\end{array}$ \\
\hline Never tan & $\begin{array}{c}9 \\
8.26\end{array}$ & $\begin{array}{c}10 \\
14.08\end{array}$ & $\begin{array}{c}19 \\
10.56\end{array}$ & $\begin{array}{c}0 \\
0.00\end{array}$ & $\begin{array}{c}6 \\
7.14\end{array}$ & $\begin{array}{c}4 \\
10.53 \\
\end{array}$ & $\begin{array}{c}9 \\
23.08\end{array}$ & $\begin{array}{c}19 \\
10.56\end{array}$ & $\begin{array}{c}6 \\
6.112 \\
\end{array}$ & $\begin{array}{c}13 \\
15.85\end{array}$ & $\begin{array}{c}19 \\
10.56\end{array}$ \\
\hline All & $\begin{array}{c}109 \\
100.00\end{array}$ & $\begin{array}{c}71 \\
100.00\end{array}$ & $\begin{array}{c}180 \\
100.00\end{array}$ & $\begin{array}{c}19 \\
10.00\end{array}$ & $\begin{array}{c}84 \\
100.00\end{array}$ & $\begin{array}{c}38 \\
100.00\end{array}$ & $\begin{array}{c}39 \\
100.00\end{array}$ & $\begin{array}{c}180 \\
100.00\end{array}$ & $\begin{array}{c}98 \\
100.00\end{array}$ & $\begin{array}{c}82 \\
100.00\end{array}$ & $\begin{array}{c}180 \\
100.00\end{array}$ \\
\hline
\end{tabular}

TABLE 4. Ability to choose the SPF filter in cosmetics for tanning.

\begin{tabular}{|c|c|c|c|c|c|c|c|c|c|c|c|c|c|c|}
\hline \multirow[b]{2}{*}{$\begin{array}{l}\text { Do you know how } \\
\text { to choose the SPF } \\
\text { filter in cosmetics } \\
\text { for tanning? }\end{array}$} & \multicolumn{3}{|c|}{ Sex } & \multicolumn{4}{|c|}{ Education } & \multicolumn{3}{|c|}{ Martial status } & \multicolumn{4}{|c|}{ Activity on the labour market } \\
\hline & $\begin{array}{c}\text { Female } \\
\mathrm{n} \\
\%\end{array}$ & $\begin{array}{c}\text { Male } \\
\mathrm{n} \\
\%\end{array}$ & $\begin{array}{c}\text { All } \\
\mathrm{n} \\
\%\end{array}$ & $\begin{array}{c}\text { Primary } \\
\mathrm{n} \\
\%\end{array}$ & $\begin{array}{c}\text { Secondary } \\
\mathrm{n} \\
\%\end{array}$ & $\begin{array}{c}\text { High } \\
\text { n } \\
\%\end{array}$ & $\begin{array}{c}\text { All } \\
\mathrm{n} \\
\%\end{array}$ & $\begin{array}{c}\text { Single } \\
\mathrm{n} \\
\%\end{array}$ & $\begin{array}{c}\text { Permanent } \\
\text { relationship } \\
\mathrm{n} \\
\% \\
\end{array}$ & $\begin{array}{c}\text { All } \\
\mathrm{n} \\
\%\end{array}$ & $\begin{array}{c}\text { Working } \\
\mathrm{n} \\
\%\end{array}$ & $\begin{array}{c}\text { Student/ } \\
\text { Unemployed } \\
\mathrm{n} \\
\% \\
\end{array}$ & $\begin{array}{c}\text { Retired/ } \\
\text { Pensioner } \\
\mathrm{n} \\
\% \\
\end{array}$ & $\begin{array}{c}\text { All } \\
\mathrm{n} \\
\%\end{array}$ \\
\hline \multirow{2}{*}{ I do not know } & 13 & 35 & 48 & 10 & 31 & 7 & 48 & 72 & 64 & 136 & 24 & 14 & 10 & 48 \\
\hline & 11.93 & 49.30 & 26.67 & 40.00 & 34.07 & 10.94 & 26.67 & 73.47 & 78.05 & 75.56 & 22.86 & 24.56 & 55.56 & 26.67 \\
\hline \multirow{2}{*}{ Incorrectly } & 42 & 11 & 53 & 7 & 21 & 25 & 53 & 20 & 5 & 25 & 26 & 23 & 4 & 53 \\
\hline & 38.53 & 15.49 & 29.44 & 28.00 & 23.07 & 39.06 & 29.44 & 20.41 & 6.10 & 13.88 & 24.76 & 40.35 & 22.22 & 29.44 \\
\hline \multirow{2}{*}{ Correctly } & 54 & 25 & 79 & 8 & 39 & 32 & 79 & 6 & 13 & 19 & 55 & 20 & 4 & 79 \\
\hline & 49.54 & 35.21 & 43.89 & 32.00 & 42.86 & 50.00 & 43.89 & 6.112 & 15.85 & 10.56 & 52.38 & 35.09 & 22.22 & 43.89 \\
\hline \multirow{2}{*}{ All } & 109 & 71 & 180 & 25 & 91 & 64 & 180 & 98 & 82 & 180 & 105 & 57 & 18 & 180 \\
\hline & 100.00 & 100.00 & 100.00 & 100.00 & 100.00 & 100.00 & 100.00 & 100.00 & 100.00 & 100.00 & 100.00 & 100.00 & 100.00 & 100.00 \\
\hline Statistical analysis & \multicolumn{3}{|c|}{$\mathrm{Chi}^{2}=32.28 ; \mathrm{p}=0.00001$} & \multicolumn{4}{|c|}{$\mathrm{Chi}^{2}=14,13 ; \mathrm{p}=0.007$} & \multicolumn{3}{|c|}{$\mathrm{Chi}^{2}=10.71 ; \mathrm{p}=0.005$} & \multicolumn{4}{|c|}{$\mathrm{Chi}^{2}=14.36 ; \mathrm{p}=0.006$} \\
\hline
\end{tabular}




\section{DISCUSSION}

Both the tan and a dark complexion are being promoted in the media as symbols of health, one's caring about themselves and high social status. This is why both pharmaceutical and cosmetic companies expand their product lines with newer and improved cosmetics boosting tanning, giving the appropriate shade of a tan or lengthening the obtained effect. These activities are influential in shaping the behavior particularly among women and men who stay single and look to be attractive to others.

Excessive exposure to UV radiation weakens the body's immune system. It exerts a large number of adverse early effects, particularly dangerous during childhood and youth, for instance: skin burns, which in time can contribute to the formation of neoplasm and late effects, as a result of the accumulation of radiation energy $[2,11,15,16]$. Avoiding the excessive exposure to natural and artificial UV radiation, appropriate pro health behaviour, correct use of photoprotection and periodic monitoring of nevi, can protect against harmful effects of UV radiation [1,17]. It is estimated that $10 \%$ of inhabitants of Europe and North America habitually use solariums $[18,19]$. Analysis performed by Public Opinion Research Centre (CBOS) in 2003 showed that $16 \%$ of Poles use solariums $[18,20]$. According to the newest reports it is estimated that the risk of developing skin cancer increases by $75 \%$ when tanning bed use started before age 30 [21].

Torzewska et al [7] have conducted research among 135 people and they found that some $38 \%$ of the respondents did not use solariums and the most frequent reason for which the respondents resigned from using tanning beds was the preference to tan in the sun.

The respondents would be able to make an informed decision to resign from the artificial sources of tanning on the basis of a large amount of information coming from the media, regarding harmfulness of this kind of tanning and not obeying the rules of safety and hygiene [1,3]. Glińska's research [22] revealed that $48.3 \%$ of respondents did not know the term skin phototype, whose knowledge conditioned a proper choice of products with filters. My own research proved that $43.89 \%$ of respondents could correctly match the right product with SPF filter to their phototype.

There is not too much research regarding the studies on behaviors and attitudes toward UV radiation, however the majority of the research on this topic concerns mainly the evaluation of knowledge and awareness in the examined population. Zalewska and Cylkowska-Nowak's research [23] showed that the media is responsible for shaping behaviour and promoting the knowledge on pro-health behaviour to the largest extent. Informative campaigns aimed at general public in the media can also have an impact on the change of inappropriate prohealth behaviors [14].

\section{CONCLUSIONS}

There is a need to encourage preventive actions and educational programs concerning the harmfulness of UV radiation in order to both spread the knowledge about it and shape the right attitudes among the society.

\section{REFERENCES}

1. Korman P, Straburzyńska-Lupa A. Solaria - za i przeciw. Fizjoter Pol. 2006;6(1):86-91.

2. Kuczyńska J, Kuczyński S. Rola preparatów chroniących przed promieniowaniem UV w profilaktyce bezpośrednich i odległych skutków ekspozycji na promieniowanie słoneczne. Now Lek. 2005;74(2):226-9.

3. Latanowicz L, Latosińska J. Promieniowanie UV a środowisko. Warszawa: Wydawnictwo Naukowe PWN; 2012.

4. Kapka-Skrzypczak L, Krasowska E, Cyranka M. Negatywne skutki zdrowotne korzystania z solarium. Zdr Publ. 2011;121(2):167-73.

5. Lesiak A, Rogalski Tylman M, Narbutt J. Wpływ preparatów ochronnych z filtrami na zdrowie człowieka. Standardy Medyczne. Pediatr. 2011;8(4):612-6.

6. Polski Związek Solaryjny, Raport o urządzeniach opalających w Polsce, Ekspertyzy i analizy dotyczące bezpieczeństwa technicznego wyrobów w Unii Europejskiej. Ministerstwo Gospodarki; 2007.

7. Torzewska K, Malinowska-Borowska J, Wypych-Ślusarska A, Zieliński G. Opalanie się w solarium - wiedza, postawa i nawyki Polaków. Environ Med. 2014;17(1):52-9.

8. Mika T, Kasprzak W. Fizykoterapia. Warszawa: Wydawnictwo Lekarskie PZWL; 2006.

9. Woźniak-Holecka J, Holecki T, Rokicka U. Sztuczne źródła promieniowania słonecznego jako czynnik ryzyka nowotworów skóry. Ann Acad Med Siles. 2009;63(6):75-80.

10. Włudyka B. Solarium-przyjaciel, czy wróg? Świat Farmacji. 2010;9:33-5.

11. Hadas E, Pogorzelska-Dyrbuś J, Pogorzelska-Antkowiak A. Patogeneza szkodliwego wpływu promieniowania ultrafioletowego na ludzką skórę. AAMS. 2002;52(53):59-72.

12. Kapińska-Mrowiecka M, Chabior A. Niektóre innowacyjne rozwiązania w ochronie przeciwsłonecznej a mechanizmy szkodliwego działania promieniowania UV na skórę. Dermatol Estet. 2007;4(51):218-24.

13. Narbutt J. Fotoimmunosupresja - jak działa promieniowanie ultrafioletowe? Dermatol. 2007;7:44-9.

14. Adamski Z, Kaszuba A. Dermatologia dla kosmetologów. Wrocław: Elsevier Urban \& Partner; 2010.

15. Smith T. Rak skóry-jak zapobiegać i leczyć. Warszawa: Wydawnictwo Lekarskie PZWL; 2010.

16. Łakomy A. Promieniowanie ultrafioletowe jako czynnik wywołujący powstawanie raka skóry, w świetle najnowszych badań. Now Lek. 2000;69(10):860-9.

17. Dana A, Makowiec-Dąbrowska T. Rola kosmetologa w profilaktyce i wczesnym wykrywaniu nowotworów złośliwych skóry. Pol J Cosmet. 2010;3:148-60.

18. Kiełtyka K. Tanoreksja - nowe zagrożenie zdrowotne. Dermatologia Estetyczna. 2008;3(56):174-81.

19. Mrozowski T. Ochrona przeciwsłoneczna. Far Pol. 2002;8(13):628-41.

20. Wojas-Pelc A, Sułowicz J, Nastałek M. Szlaki działania UV, dymu papierosowego, estrogenów na proces starzenia się skóry; możliwości prewencji. Przegl Lek. 2008;65(12):862-6.

21. Pura A. Następstwa działania promieniowania ultrafioletowego na skórę. Gabinet Pryw. 2005;6:11-9.

22. Wolnicka-Gubisz A, Płonka PM. Rola promieniowania UV w etiopatogenezie czerniaka skóry. Współcz Onkol. 2007;11(9):419-29.

23. Krajewska-Kułak E, Kowalewska B, Wróblewska K, et al. Probl Pielęg $2011 ; 19(3): 322-8$

24. Kulmaczewska MA, Krajewska-Kułak E. Postawy studentów położnictwa wobec zasad korzystania z solarium. Probl Pielęg. 2011;19(4):468-72.

25. Badania CBOS. Dbałość o własną sylwetkę, Warszawa; 2003. [http:// www.cbos.pl]

26. Glińska J, Krajewska-Kułak E, Szyszko-Perłowska A, Lewko J. Ocena wiedzy pielęgniarek i położnych na temat zasad korzystania z solarium. Probl Hig Epidemiol. 2009;3:391-7.

27. Zalewska A, Cylkowska-Nowak M. Zdrowa skóra a słońce - próba diagnozy wiedzy oraz wybranych postaw. Now Lek. 2012;81(3):214.

Corresponding author

Aneta Kamińska

7 Karmelicka Str., 20-081 Lublin

E-mail: Aneta.kaminska@umlub.pl 